\title{
Sexualidad y mujer en la filosofía: ¿amor como signo trascendente? Acercamiento a las diosas madres en América Latina
}

Sexuality and women in philosophy: is love a trascendent sign? Approach to godess mothers In latin america

Sexualidade e mulher na filosofia: amor como signo transcendente? Aproximação as deusas mães na américa latina

Fecha de entrega: 20 de septiembre de 2015

Fecha de evaluación: 30 de octubre de 2015

Fecha de aprobación: 5 de noviembre de 2015

Rosa Emilia del Pilar Alcayaga Toro*

\section{Resumen}

Este artículo parte por preguntarse si en un orden patriarcal, en esta búsqueda de sentido que no acaba, el concepto de Amor no será un nuevo signo trascendente en reemplazo o resurrección del último Dios. El Amor se perfila como uno de los pocos rasgos de trascendencia en esta civilización tecnológica que, en tanto virtud del sometimiento, el

Magister en Literatura Chilena, Mención Poesia, con su tesis "Stella Díaz Varín: sola contra el mundo. Una poeta surrealista con visos neorrománticos". Profesora de Periodismo de la Universidad de Playa Ancha, Chile. Periodista y poeta. Autora de varios libros de poesía, entre los cuales se destaca Maldito Paraíso; y numerosos artículos publicados en revistas impresas y electrónicas. Actualmente, termina su tesis en el Doctorado en Cultura y Educación en América Latina (ARCIS), con énfasis en Cultura y Género. Correo electrónico: rosaalcayaga.upla@gmail.com 
'genio del cristianismo' enlaza a la mujer en la red de la lógica cristiana regida por dos dogmas de la fe: la 'Encarnación' y el 'Amor' e impone la exclusión de las mujeres frente a la sexualidad, precio que pagarían por su admisión en lo sagrado. Este texto se propone demostrar que si bien, en América Latina, existe una persistente presencia mariana y, al mismo tiempo, se sustenta la preponderancia del papel de las diosas madres' como superadora de la visión patriarcal; desde la perspectiva de este trabajo, hay un desplazamiento que cuestiona dicha afirmación puesto que ésta no logra desestabilizar el credo cristiano. Para demostrar este argumento me apoyo en la red conceptual que ofrecen los estudios de las chicanas, en las que develan la existencia de una relación de 'unión-desunión paradójica' entre deidades católicas e indígenas en una correlación 'beligerante' en donde persiste el eje axiológico del cristianismo como dominación; caminos posibles que abren nuevas rutas para la investigación desde la noción de teoría crítica de género.

Palabras clave: sexualidad, virgen María, corriente mariana, Amor, diosas madres

\section{Abstract}

This article begins by asking whether, in a patriarchal order, love as a new transcendent sign could be the replacement or resurrection of God. Love is emerging as one of the few symbols of transcendence in this technological civilization which "in the virtue of submission", the "genius of Christianity" links women in the network of Christian logic governed by two dogmas in faith: "Incarnation" and "Love" and imposes the exclusion of women from sexuality, price to pay for admission to the sacred. This text aims to show that even though there is a persistent Marian devotion in Latin America there is also an important role of the "goddess mothers" as overcomers of the patriarchal vision; from the perspective of this work, there is a shift that challenges this claim since it fails to destabilize the Christian creed. To demonstrate this argument, I rely on the conceptual network of Chicano studies, which reveals the existence of a paradoxical relationship of connection and rupture between catholic and indigenous deities in a belligerent 
correlation with a dominant Christian core; this opens new paths for research from the perspective of gender critical theory.

Keywords: Sexuality, Virgin Mary, Marian devotion, love, goddess-mothers

\section{Resumo}

Este artigo parte de perguntar-se si em uma ordem patriarcal, nessa busca de sentido que não acaba, o conceito de Amor não será um novo signo transcendente em substituição ou ressurreição do último Deus. $\mathrm{O}$ amor perfila-se como um dos poucos rasgos de transcendência nesta civilização tecnológica que, em tanto virtude do sometimento, o "gênio do cristianismo" enlaça à mulher na rede da logica cristã regida pelos dogmas da fé: a "Encarnação" e o "Amor" e impõe a exclusão das mulheres frente à sexualidade, preço que pagariam por sua admissão no sagrado. Este texto propõe-se demonstrar que se, na América Latina, existe uma persistente presença mariana e, ao mesmo tempo, sustenta-se a preponderância do papel das "deusas mães" como superadora da visão patriarcal; desde a perspectiva deste trabalho, há um deslocamento que questiona essa afirmação dado que esta não logra desestabilizar o credo cristão. Para demostrar este argumento me apoio na rede conceitual que oferecem os estudos das chicanas, os quais desvelam a existência de uma relação de "união-desunião paradoxal" entre deidades católicas e indígenas em uma correlação "beligerante" donde persiste o eixo axiológico do cristianismo como dominação; caminhos possíveis que abrem novos rumos para a pesquisa desde a noção da teoria crítica de gênero.

Palavras-chave: Sexualidade, virgem Maria, corrente mariana, Amor, deusas mães.

\section{Introducción}

Crisis de la razón e ingreso de la sexualidad en la filosofía y la búsqueda de sentido. El hecho más elocuente del inicio de la modernidad, en cuanto fenómeno europeo, en términos de creencias, es el quiebre de la unidad cristiana en Europa. Sus rasgos, grosso modo, son: secularización del saber, consolidación de la ciencia y el avance 
del librepensamiento basados en el pilar de la razón, procesos que alcanzan su punto máximo durante el llamado Siglo de las Luces o Ilustración, en el siglo XVIII. La proliferación de actitudes críticas, sin embargo, se manifestó, a juicio de Mircea Eliade, como nostalgia e insatisfacción del intelectual europeo expresado por sus escritores y poetas.

podemos descubrir algunos secretos trágicos del intelectual moderno de Occidente: por ejemplo, su profunda insatisfacción por las formas gastadas del cristianismo histórico y su deseo de liberarse violentamente de la fe de sus antepasados, acompañado por un extraño sentimiento de culpa, como si él mismo hubiera matado a un dios en el que no podía creer, pero cuya ausencia le era imposible soportar (Eliade, 1997, p. 17-18).

Hasta la Contrarreforma, la Iglesia católica, al parecer, pudo "orientar" sin gran esfuerzo los "impulsos místicos" de una sociedad en ebullición, pero doscientos años más tarde, en el llamado Siglo de las Luces o Ilustración, cuando los filósofos racionalistas desarrollaron una radical y feroz arremetida contra del poder eclesial, sus estructuras quebrantadas estaban imposibilitadas para seguir satisfaciendo las demandas "espirituales" de sentido y del devenir que inquietaban a los seres humanos. Convergencia entre la actitud del artista y cierta nostalgia del hombre de Occidente (Eliade, 1997) frente a una insatisfacción difusa y que, según Marcel Raymond, en su libro De Baudelaire al surrealismo, habría sido el arte quien ocupó ese espacio: "Le correspondía al arte (aunque no a él solo) satisfacer algunas de las exigencias humanas que la religión había apaciguado hasta entonces” (1983, p. 9).

Resulta interesante la pregunta de Mircea Eliade acerca del curso del proceso de secularización que la razón inicia a partir del siglo XVIII: “¿en qué medida una existencia radicalmente secularizada, sin dios ni dioses, es susceptible de constituir el punto de partida de un tipo nuevo de religión?” (1996, p.14). Según Eliade, los símbolos pueden ser un remedio contra el nihilismo y el relativismo historicista que han privado al hombre moderno de todo apoyo en un sentido revelado (cf. Puleo, 1992, p. 72-73). En otros términos, para Eliade, "la desaparición de las 'religiones' no implica en modo alguno la desaparición de la 'religiosidad' en Occidente" (1996, p. 14). En esa dirección, la filósofa Alicia Puleo, en su libro Dialéctica de la sexualidad. Género y sexo en la filosofía contemporánea, señala:

No se trata de buscar nuevas creencias en culturas exóticas, sino de reconocer en esas civilizaciones remotas las mismas imágenes que Bachelard descubriera 
en la creación poética occidental. Bajo este punto de vista, la literatura aparece como aquella instancia que guardó las ancestrales imágenes arquetípicas y las defendió de la embestida racionalista al disfrazarlas de capricho subjetivo y diversión gratuita. La literatura se muestra así como la gran continuadora de los temas míticos (1992, p. 73).

Ante la evidente incapacidad de la razón, el camino de la intelectualidad y los creadores del viejo continente fue mirar a Oriente (un Oriente construido a la medida europea) y desenterrar sus mitos, entre ellos, el pensamiento analógico como elemento propio del ocultismo: analogía como correspondencia secreta entre realidad espiritual, realidad mental y realidad sensible, correspondencia que -como explica Puleo-, no puede ser aprehendida por las categorías lógicas del conocimiento y en la que, en consecuencia, se le asigna un carácter redentor a la Naturaleza. El filósofo panteísta alemán Friedrich von Schelling, uno de los teóricos del romanticismo, concibió a la Naturaleza como un organismo viviente, el cual, en cuanto organismo viviente tenía un "Espíritu” exteriorizado a través de símbolos que los poetas estaban llamados a interpretar (Alcayaga, 2009; Camacho, 2008). La asignación de un carácter redentor a la Naturaleza ya estaba presente durante la Ilustración que buscaba un nuevo paradigma legitimador.

Unido a lo anterior, a partir de la Ilustración, "el paradigma clásico de la ciencia moderna se funde y se confunde con la ciencia sexual", describe la académica Kemy Oyarzún (cf. Olea, 2000, p. 268). Desde el siglo XVIII, como hito significativo, los cuerpos y la sexualidad empezaron a medirse por la "lógica de la diferencia metafísica", que determina a hombres y mujeres, y da origen a dos naturalezas independientes y antagónicas: lo masculino y lo femenino. Dicho raciocinio simboliza un eje cardinal puesto que, esa diferencia, se explica a partir de un orden divino y natural reapropiado por la filosofía racionalista. Un cuerpo negado y reprimido, dice Oyarzún, caracterizará a la ciencia sexual desde el siglo XVIII en adelante ${ }^{1}$. En ese particular tiempo

1 En el artículo Desnaturalizar las diferencias: sexo, cultura, poder, Kemy Oyarzún sostiene que frente al discurso de la modernidad, en el que se posicionan irreducibles dos naturalezas, la masculina y la femenina, en comparación con el siglo XVI, textos como Gargantúa y Pantagruel, de Francois Rabelais (1494-1553), obra muy aplaudida por la gente, pero condenada por La Sorbona por obscena y herética, muestran que el abordaje de la temática sexual es mucho más libre y desprejuiciada. Sus argumentos remiten al análisis de los carnavales medievales de Mijail Bajtín en donde cuerpo y vida tenian un "carácter cósmico y universal", que pone en evidencia la dimensión esotérica que pervivía en la Edad Media como contracultura de los subalternos. 
de búsqueda es cuando se produce el ingreso de la sexualidad en la filosofía, de tal forma que la sexualidad pasa a ocupar un lugar "destacado" dentro de la metafísica. Este "ascenso ontológico" se produce en un período que la razón entra en crisis, justo cuando se vive el derrumbe de los grandes sistemas metafísicos y el pensamiento se siente incapaz de reconocer en la existencia un sentido que trascienda los mecanismos ciegos de la naturaleza.

En este nuevo "suelo ontológico", la sexualidad y la mujer, como su representante, serán -en opinión de Puleo-, en su mayoría, positivamente valorados. ¿Qué camino ofreció la razón a la mujer? En la era del imperio de la razón, el fundamento de la diferencia entre los sexos ya no se basaba en los dogmatismos de la fe, sino que correspondía -según los filósofos racionalistas-, al funcionamiento de las leyes del orden natural, refrendado por el avance de la ciencia. Para Elizabeth Badinter (1980; cf. Puleo, 1992), quienes impusieron sus puntos de vista a la hora de asignar un rol a la mujer fueron, finalmente, los filósofos, médicos, moralistas y hasta las autoridades policiales, lo que da por resultado que "en pleno siglo XIX nos encontramos con la familia burguesa que, en torno a la mujer-madre, reina en el ámbito de lo privado tras haber renunciado a las veleidades mundanas o intelectuales de las antiguas aristócratas" (p. 53). La mística de la madre inaugura un nuevo estatus de la mujer (que, según Puleo, recogiendo el estudio de Badinter, estaría consignado en algunos estudios de derecho en esa época), de esa forma, la mujer madre podría gozar de una mayor reputación y, hasta cierto punto, dentro del hogar, pondría un cierto límite a la autoridad del padre, como observa Badinter en su estudio acerca del controvertido tema del 'instinto maternal' (p.51).

¿Cuál es la diferencia entre la situación de la mujer bajo el despotismo y la nueva república democrática?, pregunta Lucía Guerra (1995). Le responde Montesquieu. La mujer dentro de un sistema democrático consiente libremente a encontrar, en el cumplimiento de sus deberes, la forma única y feliz de su destino, que no es otra que la maternidad, de modo que la crianza de los hijos y los deberes conyugales limitarán su quehacer (1995, p. 62). Como ciudadana de segunda clase, en el sistema democrático -agrega Guerra-, imperará el corazón que, como signo abstracto e intangible, relegará a la mujer al ámbito doméstico y al cuidado de los hijos. Entre las cuatro paredes del hogar reinaría la mujer-madre, sería el ángel de la casa, como dijo Jean Jacques Rousseau. Analizando esto en el año 2015, el filósofo Paul B. Preciado 
recuerda que, desde la perspectiva de los excluidos, hay una tarea pendiente, esto es, la redefinición del espacio democrático dentro de un movimiento de emancipación más amplio que incluye a minorías raciales, minorías colonizadas y movimientos feministas.

\begin{abstract}
Sabemos que el espacio democrático de la modernidad, que supuestamente, se abre con la Revolución Francesa y al que tanto bombo y platillo le solemos dar como un espacio ejemplar, en realidad, es excluyente. Deja afuera un conjunto de sujetos que no son reconocidos como ciudadanos de derecho. Desde el siglo XVIII asistimos a un conjunto de luchas por la redefinición de ese espacio (2015, párr. 9).
\end{abstract}

Como un curioso replay, resulta significativo destacar que el debate que marca la segunda mitad del siglo XX en Occidente, dos siglos después de su aparición, la Ilustración y la razón vuelven a generar inquietud y a ser re-pensadas, lo que para el filósofo francés Michel Foucault sería "como una forma de que Occidente tome conciencia de sus posibilidades actuales y de las libertades a las que puede tener acceso, pero también como una forma de interrogarse sobre sus límites y los poderes de los que ha hecho uso. La razón a la vez como despotismo y como luz" (2012, p. 257).

A juicio de Foucault, al menos tres argumentos sustentan dicho regreso al centro de las preocupaciones contemporáneas: uno, el peso y la influencia de la racionalidad científica y técnica en el avance de las fuerzas productivas y en las decisiones políticas (desde una perspectiva positivista que se afianza en las últimas tres décadas del siglo XIX cuando Augusto Comte ofrece a Europa la felicidad por medio de la técnica, dándole cierto aire místico: confianza en la ciencia y la tecnología como el remedio al malestar, según este filósofo, absolutamente eficaz); dos, el extravío de una esperanza que habló de revolución, de una promesa potencial de liberación que se perdió en el camino por la influencia del despotismo; tres, las preguntas que inquietan a Occidente acerca de la imposición de su racionalidad como si fuese de validez universal y que ha traducido como dominación y hegemonía política. "Una razón cuya autonomía de estructura acarrea consigo la historia de los dogmatismos: una razón, por consiguiente, que solo tendrá un efecto emancipador a condición de liberarse de sí misma”, explica Foucault (2012, p. 256). 


\section{Entrada triunfal de la sexualidad a la filosofía}

La entrada triunfal de la sexualidad a la filosofía llega de la mano de la teoría del pesimismo del filósofo alemán, declarado ateo, Arthur Schopenhauer, lo que constituye un hito en la marcha del irracionalismo por Europa con su teoría del "Inconsciente universal". Schopenhauer considera la sexualidad como el "mal supremo", puesto que sería la "culpable" de encadenar a las generaciones por venir, en otras palabras, la prefigura como "la culpa metafísica fundamental"2. Bajo esa óptica, este filósofo re-interpreta la historia bíblica e indica que el cristianismo le ofrece al hombre "alternativas éticas", que está obligado a enfrentar: Adán sería la figura de la "afirmación de la vida o sea del mal", encadenado a su expresión genealógica, mientras que Cristo sería, a su juicio, "la negación ascética salvadora”. De tal manera que la mujer, como una nueva Eva, seduce al varón para que este caiga en la trampa de la especie y, en esta re-interpretación, la serpiente sería la Voluntad de vivir (cf. Puleo, 1992, p. 24).

A partir del siglo XIX, entonces, la sexualidad ya no será algo ajeno al discurso filosófico y es acogida por la metafísica con pretensiones de trascendencia, poco a poco irá adquiriendo un espacio propio, debidamente habilitado por los nuevos valores gnoseológicos y ontológicos que se le atribuyen. Para Emmanuele Severino, la aparición de Schopenhauer en el horizonte filosófico europeo se inscribe justo en el minuto en que la razón no es capaz de combatir el miedo provocado por el devenir. Esta dimisión de la razón la interpreta, en lo que se refiere a la pregunta por el sentido, como fidelidad al origen de la misma filosofía occidental:

La episteme había sido erigida como medio de superar el terror provocado por el devenir imprevisible. Los sistemas metafísicos imponían un orden y un sentido al cambio caótico del mundo fenoménico, pero la contrapartida era el sacrificio de la libertad del sujeto en el altar de los principios superiores, trascendentes.

2 Susana Münnich Bush (2011), siguiendo a Nietzsche, sostiene en su libro Nietzsche: La verdad es mujer, que el temor al sufrimiento impulsó a los filósofos a encontrar refugio y seguridad en ciertas categorías vacias como el Ser, el alma, la inmortalidad, lo trascendente y a poner distancia de la mujer; todo lo cual no estaría muy alejado ni guarda gran diferencia de lo instaurado por los sacerdotes cristianos, quienes rechazaron la felicidad, pero no porque ella en si misma fuese despreciable, sino porque la articularon con el dolor (p. 12). En tanto, los autores Graves y Patai (1988) en Los mitos hebreos, a propósito del ideal ascético de la filosofía tradicional, cuyas raíces están asentadas desde la escritura del Génesis, señalan que el objetivo era terminar con el pensamiento matrístico y su consecuente adoración a la Diosa para dar paso al patriarcado con su Dios padre (p.25). 
La filosofía contemporánea (racionalista) procede al desmantelamiento de toda afirmación metafísica en nombre de la verdad (Severino, 1986, p. 246).

No está demás, desde una perspectiva feminista, discrepar respecto de que tal "desmantelamiento", como afirma Severino, haya dejado de lado toda afirmación metafísica. Lo que sí está claro es que la orfandad de los seres humanos, luego del desplazamiento de las religiones reveladas, no logra ser satisfecha por la razón, y, de acuerdo a Fernando Savater, con el ascenso de la sexualidad a clave ontológica, "después de la exclusión de siglos del campo de la filosofía, la sexualidad se convierte en la raíz de la comprensión del universo" (1988, p. 19).

Alejados del pesimismo, remozados discursos sobre la sexualidad tomarán el rumbo opuesto. "En tanto fundamento, la sexualidad será la Verdad y sus prácticas una vía de acceso a lo Absoluto. La razón masculina buscará en el cuerpo femenino, al que identifica con la Naturaleza, un olvido oportuno de los fracasos históricos" (Puleo, 1992, p. 63). Por el camino de la exaltación de la Mujer-Naturaleza esotérica, Europa asistió a un retorno del mito de la "hierogamia cósmica". Bajo esta figura, la "realidad se sexualiza" y todo habla de "secretas correspondencias", que Gastón Bachelard define como una "sexualización” del mundo. El rescate de la Mujer-Mesías sansimoniana, la creación de la femme-enfant o mujer paradigmática conducen a un objetivo común para la razón masculina: encontrar en el "cuerpo femenino ese Otro misterioso que es el segundo sexo" y, a través de ese Otro-misterioso, un sentido a la "angustia existencial" que el varón siente que ha perdido, como pone de manifiesto Celia Amorós (2000). La mujer adquiere los rasgos de la naturaleza redentora. Bajo esa perspectiva, el estatus femenino será considerado "por encima y fuera de lo racional”, tal como señaló, en su época, el conde Saint Simón. Mujer como mediadora, no contaminada con la razón, conocida estrategia patriarcal que tiene una base común con el cristianismo ${ }^{3}$.

En el siglo XX, hacia el final de la década de los setenta, las teorías sobre la sexualidad dieron un 'gran vuelco interpretativo'. Con Michel Foucault pasamos de una sexualidad con jerarquía de fundamento ontológico a una sexualidad definida como

3 Cecilia Sánchez señala que en la metafísica del binarismo, como carente de fines, la naturaleza, al igual que las extremidades del cuerpo humano, es concebida en términos de fuerza descabezada. En esa fuerza sin objeto, sin fines trascendentes, se ha incluido a las mujeres y también a los cuerpos fuertes de algunos hombres como el esclavo o el asalariado (2005, pp. 116-118). 
construcción cultural $^{4}$, al mismo tiempo que, como estrategia de poder, explicó que la sexualidad no es una simple realidad natural que las distintas sociedades y épocas históricas reprimen cada una a su manera, sino que es, ella misma, el resultado de un complejo proceso de construcción social. Foucault rechaza la 'hipótesis represiva' desarrollada, en particular, por los pensadores de la izquierda freudiana y abandona el esencialismo, aquella idea que suponía la existencia de una sexualidad natural deformada por la civilización. Una historia de la sexualidad -como dice Foucault-, es una "historia de los discursos", a los que define como "dispositivos de sexualidad", conjunto de procedimientos de poder tendentes a crear y a controlar el sexo de los individuos y, a través de él, a la sociedad en Occidente ${ }^{5}$. Parece apropiado recoger acá lo que Foucault dijera acerca del sexo, en una última entrevista concedida a Jerry Bauer -y que se reproduce en su libro El poder, una bestia magnifica: sobre el poder, la prisión y la vida-, publicado en español el 2012:

El sexo existe y representa el noventa por ciento de las preocupaciones de la gente durante gran parte de las horas de vigilia. Es el impulso más fuerte que se conozca en el hombre; en diferentes aspectos, más fuerte que el hambre, la sed y el sueño. Disfruta incluso de cierta mística. Se duerme, se come y se bebe con otros, pero el acto sexual -al menos en la sociedad occidental-, se considera como una cuestión del todo personal. Por supuesto, en ciertas culturas africanas y aborígenes se lo trata con la misma desenvoltura que a los demás instintos. La Iglesia heredó los tabúes de las sociedades paganas, los manipuló y elaboró doctrinas que no siempre se fundan en la lógica o la práctica. Adán, Eva y, al mismo tiempo, la serpiente perversa se convirtieron en imágenes en blanco y negro de comprensión inmediata, que podían constituir un punto de referencia aun para las mentes más simples. El bien y el mal tenían una representación esencial. La significación de "pecado original" pudo grabarse

4 Los orígenes de la tesis acerca de construcción cultural ya se encontraba en las investigaciones abiertas por la antropóloga cultural estadounidense Margaret Mead (1901-1978) con su monografía Adolescencia y cultura en Samoa (1928).

5 Paul B. Preciado señala: "Al poder hoy no se lo obedece, se lo traga. En forma de cápsulas, por la boca, o se lo absorbe por los poros. Es líquido, viscoso, aspirable e inyectable. A veces, transparente. Siempre, dispuesto a fluir. [...]. El poder ya no somete desde afuera como un aparato de ortodoncia, hace uno con el cuerpo. Se traga, también, a través de la mirada cada vez que la pantalla indica cómo hay que gozar, cómo consumir y consumar. La verdad del sexo toma forma de imperativo visual". Finalmente, Preciado nomina esta era como fármaco-pornográfica (a modo del sistema de producción económica fordista), en la cual el poder ya no es ni vigilante ni castigador, exclusivamente. En La importancia de llamarse Paul. Página 12 (párr. 8), Buenos Aires, en línea. 
de manera indeleble en las mentes. ¿Quién habría podido prever que la imagen residual iba a sobrevivir durante tantos siglos? (2012, párr. 11) ${ }^{6}$.

Ante la interrogante que Foucault plantea, es pertinente trasladar acá una temática que interpela. Cuando se le preguntó a la filósofa Julia Kristeva si era posible, desde un punto de vista laico, hablar de la "necesidad de creer", ella respondió: "Vasta empresa la de intentar comprender una necesidad de creer que yo llamo prerreligiosa y que nos confronta, ni más ni menos, con la historia de la humanidad: el ser hablante es un ser creyente" (2009, p. 13). Asimismo, Eliade (1996) afirma que cualquiera que sea el grado de desacralización del mundo al que haya llegado el hombre que opta por una vida profana, no logra abolir del todo el comportamiento religioso. Desde su punto de vista, hasta la existencia más desacralizada sigue conservando vestigios de una valoración religiosa del mundo. Elegir la ruta eliadeana lleva a considerar "lo sagrado y lo profano [como] dos modalidades de estar en el mundo, dos situaciones existenciales asumidas por el hombre a lo largo de su historia" (p. 27). El proceso secularizador emprendido en Occidente no implica, en modo alguno, la desaparición de la religiosidad -acota Eliade-, por tanto la secularización de un valor religioso, como explica este autor, constituye simplemente un fenómeno religioso y el carácter "profano" de un comportamiento anteriormente "sagrado" no presupone una solución de continuidad: lo 'profano' no es sino una nueva manifestación de la misma estructura constitutiva del hombre que, antes, se manifestaba con expresiones 'sagradas'. A juicio de Eliade, “una existencia profana depurada de todo presupuesto religioso jamás se encuentra en estado puro" (1996, p.27). Desde la perspectiva del sociólogo Pedro Morandé, en su libro Persona, matrimonio y familia (1994), la secularización del mundo moderno tiene que ver con la influencia de los filósofos de la Ilustración, hasta cierto punto un fenómeno teórico que llevó, en el Concilio Vaticano I del año 1869, a condenar la ideología modernista (1994, p. 110). Sin embargo, sostiene Morandé:

Pienso que el gran desafío para la Iglesia de este siglo [XX] ha sido precisamente esta tesis del cristianismo sin Iglesia. Mucho más que el ateísmo propiamente tal, puesto que vemos por todos lados un gran despertar religioso, en el Islam, en las sectas, en la penetración de teosofías orientales, en la new age. No es

6 Entrevista que Michel Foucault le concedió a Jerry Bauer, traducida al español e incluida en el libro El poder, una bestia magnifica, en donde el filósofo da testimonio de la actualidad de las ideas: la locura, el dominio y la sexualidad en un diálogo que es, al mismo tiempo, un repaso de su trayectoria. 
que el mundo ya no le dé importancia a lo religioso, sino que el problema es que piensa que es posible una religiosidad que no necesita institucionalizarse porque corresponde a una necesidad individual que cada quien busca satisfacer de la manera que le parece más adecuada. En nuestro medio también esta tendencia ha sido fuerte $(1994, \mathrm{p} .111)^{7}$.

Por su parte, Octavio Paz, en su libro El arco y la lira, enuncia que el hombre moderno tiene nostalgia del mundo divino y que los numerosos y variados estudios sobre los mitos, la magia y las religiones pueden emparentarse con otras aficiones contemporáneas como el arte primitivo, la psicología del inconsciente, la tradición oculta o la astrología. Según el Nobel mexicano, estas preferencias no son casuales y, en su opinión, estas inquietudes revelan una forma de sustituir una ausencia, algo así como intelectualizar la nostalgia que los seres humanos sentirían de lo divino. (pp. 117-118)

\section{Amor y las diosas madres en Latinoamérica}

Preguntarse, entonces, si en un orden patriarcal, en esta búsqueda de sentido, que no termina de inquietar a Occidente, tal como lo hace Oscar del Barco, en el prólogo al libro Genealogía de la modernidad, del autor Vincenzo Vitiello (1998), el concepto de Amor no será un nuevo signo que reaparece en la contemporaneidad como otro signo trascendente en reemplazo de o como resurrección del último Dios, interrogante que debe merecer, al menos, un instante de reflexión puesto que cualquier ética en un mundo donde la "trascendencia" opera, no debemos olvidar que lo hace de manos de un poder.

Así, se puede entender el Amor como uno de los pocos rasgos de trascendencia en esta civilización tecnológica, como comenta la filósofa Puleo: “sin esa identidad

7 Escribe Pedro Morandé: "El Concilio Vaticano I (1869) reafirma, justamente, la estructura dogmática de la Iglesia para defender la posición cristiana frente a la gran filosofía, especialmente frente a quienes negaban a Dios o proclamaban su muerte. Sin embargo, la Iglesia comienza a darse cuenta en el siglo XX que el modernismo y su olvido de Dios constituyen un problema fundamentalmente práctico, no teórico, y que se relaciona con la organización de la sociedad. Este es el enfoque que subyace al Concilio Vaticano II (1959). El modernismo es un problema de la cultura y de la vida cotidiana del hombre. La gente se ha apartado de Dios no porque un filósofo haya dicho que Dios murió o porque un filósofo haya escrito que ahora lo que corresponde no es contemplar el mundo sino transformarlo. El mundo se ha ido alejando de la fe porque ha cambiado su organización, ha cambiado su manera de asociarse, han entrado en crisis muchas instituciones. Entre ellas, la familia". (1994, pp. 110-111) 
femenina construida sobre el pudor, la humanidad perdería uno de los pocos rasgos de trascendencia que le quedan en esta civilización tecnológica: el amor. [...]. La crítica suele detenerse a menudo cuando se llega al terreno del sexo-género y la sexualidad" (p. 90). Para esta autora, es esa "artificialidad del pudor", la que encubre "su carácter de virtud del sometimiento" y subraya que, para los valores masculinos, hasta los más osados críticos sellan el sacrificio de las mujeres, como, por ejemplo, pueden hacerlo audaces representantes de las teorías críticas, quienes suelen detenerse, en ese punto, cuando se llega al terreno de la sexualidad. ${ }^{8}$ Amor que, en cuanto virtud del sometimiento, el "genio del cristianismo" enlaza a la mujer en la red de la lógica cristiana regida por dos dogmas de la fe: la 'Encarnación' y el 'Amor', como señala Julia Kristeva (2009). Esta autora destaca lo asombroso de la arquitectura ideológica del cristianismo en la construcción de la ecuación algebraica amor y mujer: María, madre de Dios, pieza clave en la construcción de la subjetividad cristiana. El dogma de la Encarnación como lo enuncia ya San Bernardo (70 d.C.), a los cristianos de su época, a través de una interrogante: “¿Por qué buscáis entre palabras muertas el Verbo cuando Él, al hacerse carne, se ha hecho visible?” (citado en Morandé, 1994, p. 123). Al respecto, subraya Kristeva:

En efecto, es a través de la mujer como actúa la Encarnación: el cuerpo de María es indispensable para la llegada al mundo visible del Dios-Padre invisible. Sin embargo, no es su cuerpo como tal lo que hay que hacer aparecer, sino un cuerpo enamorado; el amor es, por lo tanto, esa asunción de sí mismo y ese entregarse al otro cuyo grado más alto, dirá Hegel, es la "identificación del sujeto con otra persona de otro sexo". Basado en el deseo, el amor sería la "relación física espiritualizada" que atrae todo a su órbita y que no les adjudica un valor a los objetos sino en la medida de su vinculación con el amor. "Es sobre todo en los caracteres de las mujeres que se revela en toda su belleza", concluye la Estética hegeliana (El arte romántico, 1835-1838). Nunca se insistirá lo suficiente sobre el genio del cristianismo que enlazó la suerte del amor a la mujer (2009, pp. 91-92).

8 Puleo pone de ejemplo al filósofo y sociólogo alemán Max Horkheimer (1895-1973), representante de la Escuela de Frankfurt, que apoyó la prohibición del uso de anticonceptivos artificiales a los católicos, que decretó el papa Pablo VI, en una de sus encíclicas: entre sus fundamentos, Horkheimer decía que con el uso de la pildora se decretaba la muerte del amor erótico. "La 'pildora' hemos de pagarla con la muerte del amor erótico [...] Si se quita el tabú de lo sexual se derrumba con ello la barrera que fomenta el anhelo, perdiendo el amor su base" (Horkheimer, M. (1976). A la búsqueda de sentido (p.14, en Puleo, p.90). 
La castidad impone la exclusión de las mujeres de la sexualidad, a condición, como destaca esta autora, de que la mujer-madre asuma su parte de sacrificio bajo la forma de pureza. En esta temática, claramente, Kristeva asume una posición:

El escándalo principal es su virginidad: la simple razón y nuestra sensibilidad no pueden sino denunciar el horror discriminatorio que esa virginidad impone, la exclusión de las mujeres frente a la sexualidad, una castidad punitiva que parece ser el precio a pagar por la admisión de las mujeres en lo sagrado - iy en la representación!-”. (2009, p. 98)

No obstante, para la antropóloga Sonia Montecino, en su libro Madres y huachos. Alegorías del mestizaje chileno (1991), respecto del culto mariano, existirían algunas 'diferencias' entre lo que piensa Europa respecto de la virginidad de lo que sucede en América Latina. Montecino afirma que "el asunto de la virginidad no es la cualidad dominante del símbolo mariano" en Latinoamérica (1991, p. 88). Parafraseando al sociólogo Pedro Morandé (1980), para sustentar su argumentación, Montecino rescata lo que el sociólogo sostiene: "las disquisiciones sobre la Concepción Inmaculada no han arraigado en el pueblo [...] toda vez que éste vive la ritualidad y el mito, precisamente, en el plano de la oralidad y no en el de la textualidad". Desde lo afirmado por Morandé, Sonia Montecino explica: "El enigma de la virginidad de María corresponde más bien a la cultura de la palabra” (pp. 88-89)

Para este artículo sería un tema a debatir por cuanto no puede desconocerse que el signo 'virginidad', como figuración simbólica, en definitiva, lo que expresa en la práctica es la internalización de una imagen que obliga a la renuncia del placer, placer que los filósofos judeocristianos y racionalistas intentaron suprimir, que en cuanto a la mujer instituye una disociación entre sexualidad y reproducción, no así en el hombre, de tal forma que tenemos una minoría de putas y una mayoría de madres (Paola Tabet, 2009). La figura sagrada de María, al mismo tiempo que venerada, tiende a "nuestra femineidad" una serie de trampas desde hace dos mil años, porque reduce el cuerpo de la mujer al oído y a las lágrimas, en una suerte de beatificación del sufrimiento y del dolor: "el papel mariano es ciertamente envidiable, pero exige sumergirse totalmente en el sufrimiento: las malas conciencias dirán que María de pruebas de una excepcional predisposición masoquista" (Kristeva, 2009, p. 100) Y como mediadora o intercesora ante Dios, papel muy valorado en el cristianismo, la virgen María está dispuesta a soportar sobre sus espaldas, todos los golpes en contra 
de sus hijos, tanto que muchos -cínicamente, creo-, aseguran que María tiene una predisposición masoquista; pero no ha sido ella la que ha prefigurado este comportamiento, el imaginario masculino, desde la perspectiva de un 'erotismo fálico', connota como 'bellas' las manifestaciones de debilidad y sometimiento de la mujer.

Igualmente, dentro del esquema del Amor cristianizado, quizás por razones económico-históricas tanto como biológicas, como apunta Kristeva, la sexualidad femenina quedó amarrada al ideario cristiano y fue insertada en la lógica de la conyugalidad y la fidelidad, a imagen del lazo que une a Cristo con su Iglesia en el bien y el mal. A diferencia de lo que sucedió en Grecia -dice Marcela Lagarde (1997) —, en el pensamiento cristiano es imprescindible el nexo de la relación sexual con el matrimonio puesto que la primera relación sexual, en sí misma, llevaría las marcas del pecado, de la caída y del mal: al efectuarse el matrimonio, éste le daría esa legitimidad perdida, lo que no garantiza que deje de ser pecado. "En la ideología dominante de contenido católico, el cuerpo de la mujer es un espacio sagrado y, por ende, objeto del tabú: en él se verifica la creación de cada ser humano, una y otra vez, como un ritual" (Lagarde, p. 13, párr. 94 en línea).

Lagarde también destaca que "María no es espacio del eros. María es sólo vientre, sólo matriz...de tu vientre, Jesús" (1997, p.13, párr. 95), de tal forma que María no vive el coito, eso significa que el pecado no está presente, como lo está en la concepción de los seres humanos: el pudor y la decencia que exigían los griegos, bajo el cristianismo (y el racionalismo) se transforma en castración sexual. Una interrogante válida en este ejercicio, siguiendo a Lagarde, sería si ¿son las mujeres sujetos del goce, existe su cuerpo como espacio del placer? La respuesta de esta autora es que las mujeres no gozan y que "las mujeres buenas son como María" (p. 14, párr. 97). María como mujer-madre que, para Kristeva, al asumir su parte de 'sacrificio' bajo el manto de pureza en una suerte de 'negociación' entre placer del uno y sufrimiento de la víctima, es donde - acota esta autora- el Amor adquiere un sentido de belleza. "Descubrimos entonces que los matices del amor están reservados, no exclusivamente, pero con una particular insistencia, a la femineidad. Maternidad, seducción, crueldad: la gama de la belleza psíquica se torna una economía de lo femenino" (Kristeva, 2009, p. 94).

Con el correr de los siglos y ante la presión del paganismo popular, la presencia mariana aumenta, hay un deseo de consolidar el papel de las diosas-madres dentro 
del monoteísmo triunfante, en particular en Latinoamérica9 ${ }^{9}$ La imagen de la virgen María, sin embargo, ha sido una imagen discreta en los Evangelios: cabe recordar que recién es nombrada Madre de la Iglesia a partir de 1964, quizás como una forma que el catolicismo adopta para no perder ese capital humano de apoyo, quizás para recuperar a las mujeres apoyándose en la imagen de la Virgen. En América Latina existe una vigorosa corriente mariana, en opinión de Sonia Montecino (1990), la que, a su juicio, determina la existencia de una denominada "identidad cultural latinoamericana", en la que predominaría la figura femenina como parte sustancial en la configuración de nuestro ethos. Idea desarrollada, entre otros, por Jorge Guzmán, Pedro Morandé y Octavio Paz, mencionados por la antropóloga citada. A juicio de Montecino, el proceso de mestizaje social y sincretismo religioso en América Latina ha favorecido un "simbolismo centrado en la madre", por el cual la cultura mestiza se re-apropiaría del modelo mariano dándole otro sentido:

\begin{abstract}
La conquista de América, parafraseando a Wachtel ${ }^{10}$, trajo como consecuencia la derrota de los dioses masculinos y el triunfo de las diosas-madres. En casi todo nuestro territorio se extendió la figura sincrética de la Virgen María fusionada con las divinidades femeninas vernáculas, como un símbolo que eclipsó - y eclipsa - al de Dios-Padre. La Virgen de Guadalupe en México, la de Copacabana en Perú y Bolivia, la Tirana y la del Carmen en Chile, entre otras, dibujan la silueta de lo femenino poderoso que domina el panteón del mestizo latinoamericano (Montecino, 1990, p. 285).
\end{abstract}

Es indudable que no puede pasarse por alto una religión católica profundamente arraigada, heredada de tres siglos coloniales, frente a la cual no hubo una verdadera revolución, religión que condicionaría a América Latina de manera vigorosa, sostiene Jorge Larraín (2009). Y los rasgos culturales de dicha herencia determinarían el

9 Sabido es que la iconografía pagana ginocéntrica recoge la idea mítica de una "Madre divina que da vida", que "proporciona alimento", como señala Eisler (2004, p. 22), figura de madre que podría asimilarse a Diosa madre "como la proveedora omnipotente y generosa de amor, alimento y plenitud" (Moi, 1988, p. 124).

10 En el libro Los vencidos, obra pionera del historiador y antropólogo francés Nathan Wachtel, este mostraria la voluntad explicita de romper con una tradición historiográfica marcada por el eurocentrismo. Este viraje de la mirada estuvo acompañado por un esfuerzo no menos notable en desarrollar una reflexión teórica y epistemológica con respecto a los caminos a seguir para dar cuenta de la historia de los pueblos hasta ese entonces llamados "primitivos" o definidos de manera negativa como "sin historia", "sin escritura" o "sin estado". 
carácter que esos procesos han asumido desde entonces. Por otra parte, los líderes de los movimientos independentistas latinoamericanos, que traían bajo el brazo algunas lecciones de la Ilustración, permiten afirmar que ambos factores, tanto la herencia de España con la religión católica y la Contrarreforma como los líderes que copiaron de la Europa liberal los postulados de la Ilustración y trajeron la filosofía racionalista, de una u otra forma impusieron a la mujer un discurso patriarcal bajo la metafísica del binarismo. Si este proceso de mestizaje y sincretismo que sitúa a la Madre como figura fundante de un orden pareciera ser lo propio de nuestro continente, un ethos mestizo que hiperboliza lo materno, cabe preguntarse, entonces, como igualmente lo hizo Sonia Montecino: ¿Cómo se realiza el patriarcado y la subordinación de la mujer en nuestra cultura? ¿Cómo se estructura la Ley del Pater en nuestro territorio? ¿Cuál es el eje dominante que funda la alteridad? Respecto de la presencia del modelo mariano en nuestro continente, la propia antropóloga reafirma esta inquietud:

\begin{abstract}
Interrogando los discursos de algunas mujeres chilenas de clase media pudimos constatar la vigencia en ellos del modelo de constitución de identidad mariana. La autodefinición de las mujeres se posa, indefectiblemente, en la palabra madre. "Soy madre de tantos hijos", dicen las profesionales, sin delimitarse en primera instancia en su "oficio", en lo que las califica "productivamente" en la estructura económica. El sí mismo femenino está anclado en lo privado de reproducir, criar, amamantar, querer antes que nada a sus hijos. Y no es sólo la maternidad biológica la que aparece, también la maternalización de los trabajos, de las relaciones, de la visión del mundo, están presentes en la auto-mirada de las mujeres (con hijos o sin hijos) (1990, p. 290 $)^{11}$.
\end{abstract}

Con el auxilio de nuevas herramientas de análisis es posible escudriñar el proceso de mestizaje y sincretismo en América Latina en donde las diosas madres habrían derrotado a los dioses varones, como afirma Sonia Montecino. Lo anterior lleva a plantear una inquietud menos optimista que la formulada por la antropóloga y otros autores, en virtud de que no es aventurado sostener que las lógicas del cristianismo, reapropiadas por la modernidad y las ideas de la Ilustración, que reproducen aquello de una madre sufrida y abnegada, cuya virtud del sometimiento seguiría operando en la construcción

11 Estos discursos son casi una treintena de historias de vida que realizamos junto a Mariluz Dussel y Angélica Willson, para la investigación "Modelo Mariano y Constitución de la Identidad Femenina Chilena" del Centro de Estudios de la Mujer, cuyos resultados están publicados en el libro Mundo de Mujer: continuidad y cambio. Santiago: CEM, 1988. 
de su subjetividad y en el "imaginario histórico" (Pierre Bourdieu, 2000), es lo que induce, en este artículo, a problematizar, desde la teoría crítica de género -a modo de provocación y de futuras investigaciones-, estas imágenes de vírgenes sincréticas, denominadas por Montecino como diosas-madres, y revisar, desde este siglo XXI, ciertas afirmaciones acerca de los procesos culturales en el continente americano.

Es necesario dar una mirada crítica, en primer lugar, a los términos 'mestizaje' y 'sincretismo'. En su libro Voces híbridas, Stacey Alba D. Skar (2001) lleva a cabo una apretada síntesis de la cartografía de este debate y sostiene que si bien estos conceptos siguen siendo usados, éstos han sido reexaminados y superados en las últimas décadas ${ }^{12}$. La pregunta que guía su exposición es: ¿ ¿de qué manera y con qué herramientas conceptuales puede estudiarse la "heterogeneidad americana"? Para la ensayista está claro que es necesario buscar conceptos alternativos para definir esa mezcla de culturas (2001, pp.13-23). Uno de los aspectos más criticados es el carácter reduccionista de los conceptos mestizajes y sincretismo frente a la heterogeneidad del continente puesto que no daría cuenta de un proceso que podríamos calificar de 'chirriante y paradójico'. En ese sentido, entre los autores consultados, es necesario subrayar lo que sostiene Antonio Cornejo-Polar (1997): este investigador dice que el problema del mestizaje, en cuanto concepto, tal y como fue concebido ofrece "imágenes armónicas de lo que obviamente [en nuestro continente] es desgajado y beligerante"; a juicio de Cornejo-Polar dichos conceptos proponen figuraciones que, en el fondo, no son pertinentes, puesto que de aceptarlos sería aceptar en nuestras sociedades una supuesta armonía sin fisuras.

Varias veces he comentado que el concepto de mestizaje, pese a su tradición y prestigio, es el que falsifica de una manera más drástica la condición de nuestra cultura y literatura. En efecto lo que hace es ofrecer imágenes armónicas de lo que obviamente es desgajado y beligerante, proponiendo figuraciones que en el fondo solo son pertinentes a quienes conviene imaginar nuestras

12 Como alternativa paradigmática, Néstor García Canclini desarrolla lo que él llama "proceso de hibridación", en vez de usar mestizaje y sincretismo como amalgama histórica [fusión, mezcla, mezcolanza, mixtura, composición] de dos discursos o identidades; dice él que las culturas e identidades hibridas permiten y exigen la permanente transmutación de fronteras móviles y a veces esquizofrénicas para las subjetividades que las incorporan y que deben entrar y salir de ellas. La hibridación en la definición de García Canclini se relaciona además con la subjetividad migratoria entendida como producto de tensiones entre la desterritorialización y la reterritorialización. Antonio Cornejo-Polar critica el paradigma de la hibridación señalando los peligros de su exaltación armoniosa. Una crítica semejante se ha hecho a la teoria de la hibridez propuesta por Homi Bhabha. 
sociedades, como tersos y nada conflictivos espacios de convivencia. En otra ocasión también me he detenido en el mal uso de la vida y obra de Garcilaso como mestizo simétrico de una nación tan mezclada que ya formaría una unidad sin fisuras (1997, p. 341).

Las escritoras y poetas chicanas, entre ellas, Gloria Velásquez, Tey Diana Rebolledo, Gloria Anzaldúa o Pat Mora en Estados Unidos aportan, desde esa realidad fronteriza, con nuevas miradas y, asimismo, deconstruyen, en sus textos literarios, los conceptos como mestizaje y sincretismo. Un número considerable de chicanos y chicanas incorporan dentro de esa conciencia fronteriza las figuras arquetípicas femeninas más conocidas, dentro de la cultura mexicana, como la Malinche, la Llorona y la Virgen de Guadalupe. Pero existen ciertos colectivos de algunas mujeres chicanas feministas, Pat Mora, por ejemplo, que han criticado la naturaleza opresiva de estos tres arquetipos y se observa un intento de redefinición de esas figuras prototípicas, tendencia particularmente visible en la escritura de las chicanas. Prima el interés por deconstruir el legado opresivo de estas tres madres míticas y "desenmascarar la romantización de la 'Madre Ideal'". En algunos casos, este proceso se viabiliza también mediante una redefinición de la maternidad enfocada en su poder creativo, desde una cosmovisión pre-patriarcal, trabajo literario que, al parecer, logra ofrecer alternativas al modelo socio-cultural de la madre sufrida y abnegada, lo que Octavio Paz denomina 'la chingada'.

\section{Problematizar la figura de la Virgen de Guadalupe como diosa madre sincrética}

No obstante, ha sido la representación de la Virgen de Guadalupe que, para este texto, reviste especial interés, una de las figuras arquetípicas mexicanas (más conocida en el continente americano) que concentró mayor crítica de parte de algunos colectivos de escritoras chicanas acerca de los posibles peligros asociados con la definición romántica del mestizaje y del sincretismo armonioso, arquetipo que sirvió -escriben estas autoras-, en la consolidación de la Conquista y para acallar la religiosidad indígena (en Stacey Alba D. Skar, 2001).

Acerca de la emergencia de la Virgen de Guadalupe, según el milagro que cuenta la tradición, a un indígena, recién convertido a la religión católica, se le aparece la figura de una Virgen morena. En esa supuesta deidad sincrética se entrelazan aspectos de la 
Virgen María de la tradición católica y la diosa precolombina Tonantzin, madre de los indígenas. Su visión de una Virgen mestiza creó el mito capaz de enmascarar una devoción perpetuada de la deidad precolombina en otra poderosa "madre" espiritual aceptada por los conquistadores que no permitían la continuación de las creencias mitológicas mesoamericanas. Así nació la veneración, que sigue hasta el presente, de la Virgen de Guadalupe. Al respecto, Octavio Paz, en su texto, Sor Juana Inés de la Cruz o las trampas de la fe, afirma:

\begin{abstract}
Virgen fue y es algo más, y de ahí que haya sobrevivido al proyecto histórico de los criollos. La Virgen es el punto de unión de criollos, indios y mestizos y ha sido la respuesta a la triple orfandad: la de los indios porque Guadalupe/ Tonantzin es la transfiguración de sus antiguas divinidades femeninas; la de los criollos porque la aparición de la Virgen convirtió a Nueva España en una madre más real que la de España; la de los mestizos porque la Virgen fue y es la reconciliación con su origen y el fin de su ilegitimidad (1992, pp. 63-64).
\end{abstract}

En otras palabras, para Paz y para los conquistadores españoles esta nueva Virgen mestiza servía de consuelo al pueblo indígena y facilitaba la sumisión. Al respecto Tey Diana Rebolledo (1995, p. 52), quien traza el desarrollo de la literatura chicana desde 1848 hasta el presente en Estados Unidos, sostiene que es la Virgen María la que triunfa sobre Tonantzin y domina la relación espiritual. Desde la perspectiva de Rebolledo significa que mientras se mezclaban-sintetizaban las imágenes de Tonantzin/Coatlicue y la Virgen de Guadalupe, los aspectos poderosos de Tonantzin desaparecieron. Si bien esta nueva Virgen que transformaba a la Virgen María y esta última admitía rasgos étnicos e históricos de Tonantzin, pero era la figura de tradición católica la que dominaba la relación espiritual.

La escritura de autoras chicanas ha reprocesado los conceptos de mestizaje y el sincretismo a la vez que han sugerido otros. Por ejemplo, Gloria Anzaldúa afirma que la conciencia heterogénea que caracteriza la perspectiva fronteriza es una subjetividad nepántlica ${ }^{13}$. En tanto, algunas poetas chicanas desean transformar realidades socioculturales y sexuales mediante la recuperación de mitos y cosmologías femeninas: esto se observa en sus poderosas redefiniciones de figuras míticas e históricas como la

13 Nepantla es un término que viene del náhuatl y que significa "el lugar en el medio", se asemeja al concepto de "tercer espacio" (Moreiras) o perspectiva intersticial o liminal que Bhabha relaciona con la hibridación. 
diosa de Coatlicue, la Virgen de Guadalupe, la Malinche y la Llorona. En el caso de la poeta Gloria Velásquez que, en su poema “¿Quién soy?” hace una revisión mitológica de la Virgen de Guadalupe, en su papel como opresora del pueblo indígena, pero no como un proceso lineal, sino como una re-semantización mítica e histórica de la identidad formada en una zona de contacto (2001, p.19); Velásquez escribe: "Soy la Virgen de Guadalupe / mi imagen fue usada por padres opulentos / para convertir a mi pueblo indígena" (p.111), lo que analizado desde la perspectiva de Mijaíl Bajtín, en su teoría acerca de la novela, este autor describiría como heteroglosia, esto es, una trama de diversos lenguajes socio-ideológicos, que se resiste a la homogeneidad (cf. Madariaga, 2015, pp. 7-8). Sobre el particular y, a modo de síntesis, una de las conclusiones a las que llega Stacey Alba D. Skar en su libro Voces híbridas:

Las voces híbridas y migrantes cambian de código constantemente entre sistemas socio-simbólicos y logran problematizar fronteras rígidas, señalando su naturaleza móvil y borrosa. Se muestra, además, la capacidad que tiene esta literatura de promover la heterogeneidad sin convertirla en utopía armoniosa ni condenarla a la misma categoría de homogeneización que intentaría desestabilizar. Un intento de redefinir la identidad híbrida no como una reconciliación de lo dominante con lo subalterno sino como la mediación intercultural entre los dos. Capacidad de las construcciones de la hibridez para elaborar subjetividades que socavan los discursos hegemónicos, pero sería idealismo sugerir que tienen capacidad de hacer cambios reales a nivel (trans)nacional (2001, p. 121).

De acuerdo al trabajo que desarrollan las escritoras y poetas chicanas, pudiera afirmarse que la imagen de la Virgen de Guadalupe conserva los mismos atributos permitidos en ella por la tradición católica. Por ende, en vez de ofrecer un modelo paradigmático de hibridez o una transgresión espiritual de la opresión europea, históricamente, la Virgen se habría convertido en una herramienta adicional de conquista y colonización. De hecho la Virgen de Guadalupe se ofrece como ejemplo de los posibles peligros asociados con la definición romántica del mestizaje y del sincretismo en armonía, porque, en realidad, habría servido de apoyo para mantener la Conquista, y, efectivamente, intentar silenciar las tradiciones religiosas de los indígenas o al menos enmascararlas ${ }^{14}$.

14 "Aunque se veneraba una multitud de deidades femeninas, el control político y religioso sin embargo pertenecía a los hombres además de una notable división jerárquica entre clases sociales" (Voces hibridas, 2001, p.109) 
Sin embargo, al repasar los escritos y opiniones de la escritura de las mujeres chicanas, el mayor impacto de la devoción católica hacia la Virgen de Guadalupe, así como a la Virgen María, es la opresión de la mujer mexicana y chicana ya que, como arquetipo de la femineidad ideal, ha servido para silenciar a la mujer y encarcelarla en su papel tradicional de madre imperfecta y "chingada". En este sentido, el aporte del trabajo literario y ensayístico de las chicanas abre una ventana en la dirección que guía este artículo: auscultar con atención el fenómeno de las diosas madres que tienen vida a través de las distintas vírgenes latinoamericanas, pero que al parecer -es la propuesta a desarrollar en sucesivas reflexiones-, no desestabilizan el credo cristiano; lo valioso de ese trabajo apunta a no privilegiar una u otra tendencia, sino a reconocer que existe una 'unión-desunión paradójica' de deidades católicas e indígenas en relación "beligerante", utilizando el concepto que propone Cornejo-Polar, o bien el término 'nepantla' que rescatado del náhuatl, Gloria Anzaldúa proyecta como posible para representar la heterogeneidad cultural, son caminos que abren nuevas rutas para la investigación desde la noción de la teoría crítica de género ${ }^{15}$.

\section{Referencias}

Alcayaga, R. (2010). Stella Díaz Varín. Sola contra el mundo. (Una poeta inscrita dentro de la vanguardia surrealista que despierta ecos neorrománticos). (Tesis de Magíster inédita). Universidad de Playa Ancha, Valparaíso, Chile.

Amorós, C. (1994). Historia de la teoría feminista. En Dos categorías de análisis que nos aporta la teoría feminista. Patriarcado y género. Recuperado octubre 2014 de: http://www.larevuelta.com.ar/articulos/ST_2010_01_31_c.html

Amorós, C. (2000). Elogio de la vindicación. En R. Olea (Ed). Escrituras de la diferencia sexual (pp. 15-28). Santiago de Chile: LOM Ediciones/La Morada..

Bourdieu, P. (2000). La dominación masculina. Barcelona: Editorial Anagrama.

15 Concluyo con la afirmación del filósofo Paul B. Preciado, hecha en una entrevista a Página 12, en línea, 5 de junio 2015, bajo el título "La importancia de llamarse Paul":

-Accedo a la testosterona, sin ver diferencia entre ella y la filosofía, dice el filósofo.

- ¿Por qué no hay diferencia?

-Ambas son técnicas de producción de subjetividad. 
Camacho, G. J. E. (2008). Naturaleza y libertad en Schelling. (Tesis de maestría). Universidad Javeriana, Bogotá, Colombia. Recuperado de: http://repository. javeriana.edu.co/bitstream/10554/6253/1/tesis14.pdf

Centro de Estudios de la Mujer (1988). Mundo de Mujer: continuidad y cambio. Santiago: Ediciones CEM.

Cornejo-Polar, A. (1997, julio-septiembre). Mestizaje e hibridez: Los riesgos de las metáforas. Revista Iberoamericana LXIII, 180, 341-344.

Eisler, R. (1995). El cáliz y la espada. Santiago de Chile: Editorial Cuatro Vientos.

Eliade, M. (1997). Ocultismo, brujerías y modas culturales. Barcelona: Editorial Paidós.

Eliade, M. (1996). Lo sagrado y lo profano. Colombia: Editorial Labor.

Foucault, M. (21 de septiembre 2012). Michel Foucault: la máxima aspiración del poder es la inmortalidad. La Nación. Recuperado de: http://www.lanacion.com. ar/1509936-michel-foucault-la-maxima-aspiracion-del-poder-es-la-inmortalidad

Graves, R. y Patai, R. (1988). Los mitos hebreos. Madrid Alianza Editorial.

Guerra, L. (1995). La mujer fragmentada: Historias de un signo. Santiago de Chile: Cuarto Propio.

Guerra, L. (2000). Introducción. En L. Guerra (Comp.). María Luisa Bombal. Obras completas. (pp.7- 49). Santiago de Chile: Editorial Andrés Bello.

Kristeva, J. (2009). Esa increíble necesidad de creer. Un punto de vista laico. Argentina: Editorial Paidós.

Lagarde, M. (1997). La sexualidad. En Los cautiverios de las mujeres: madresposas, monjas, putas, presas y locas. Recuperado de: http://www.creatividadfeminista. org/articulos/sex_2003_lagarde.htm\#introduccion

Larraín, J. (2011). ¿América Latina moderna? Globalización e identidad. Santiago de Chile: Editorial LOM.

Madariaga, M. (2015). La heteroglosia en la frontera. Rituales de autonomía enBorderlands/La Frontera: The New Mestiza (1987) de Gloria Anzaldúa y Recado confidencial a los chilenos (1999) de Elicura Chihuailaf. (Tesis de Magíster inédita). Pontificia Universidad Católica. Valparaíso, Chile. 
Moi, T. (1988). Teoría literaria feminista. España: Cátedra.

Montecino, S. (1990). Símbolo mariano y constitución de la identidad femenina en Chile. Revista Estudios Públicos, (38), 283-290.

Montecino, S. (1991). Madres y huachos. Alegorías del mestizaje chileno. Santiago de Chile: Editorial Cuarto Propio - CEDEM.

Morandé, P. (1994). Persona, matrimonio y familia. Santiago de Chile: Ediciones Universidad Católica de Chile.

Morandé, P. (1980). Ritual y palabra. Lima: Centro Andino de Historia.

Münnich, S. (2011). Nietzsche: La verdad es mujer. Santiago de Chile: LOM Ediciones.

Oyarzún, K. (2000). Desnaturalizar las diferencias: sexo, cultura, poder. En R. Olea. Escrituras de la diferencia sexual (pp. 267-284). Santiago de Chile: LOM Ediciones/ La Morada.

Paz, O. (1979). El arco y la lira. México: Fondo de Cultura Económica.

Paz, O. (1990). Sor Juana Inés de la Cruz o Las trampas de la fe. México: Editorial Seix Barral.

Paz, O. (1999). El laberinto de la soledad. Postdata. Vuelta a El laberinto de la soledad. Chile: Fondo de Cultura Económica.

Preciado, P. B. (5 de junio 2015). La importancia de llamarse Paul. Página 12, Buenos Aires. Recuperado de: http://www.pagina12.com.ar/diario/suplementos/soy/14022-2015-06-10.html

Puleo, A. (1992). Dialéctica de la sexualidad. Género y sexo en la filosofía contemporánea. España: Ediciones Cátedra, Universitat de València, Instituto de la Mujer.

Raymond, M. (1983). De Baudelaire al surrealismo. España: Fondo de Cultura Económica.

Rebolledo, T. D. (1995). Women Singing in the Snow (Mujeres que cantan en la nieve: un análisis cultural de la literatura chicana). Estados Unidos: Paperback.

Sánchez, C. (2005). Escenas del cuerpo escindido. Ensayos cruzados de filosofía, literatura y arte. Universidad ARCIS/Editorial Cuarto Propio. 
Savater, F. (1988). Génesis del pesimismo genital. En F. Savater (Ed). Filosofía y sexualidad (p.19). Barcelona: Anagrama.

Severino, E. (1986). Schopenhauer: El ocaso de la razón como remedio. En E. Severino (Ed). La filosofía contemporánea (pp.245-247). Barcelona: Ariel Filosofía.

Skar, S. A. D. (2001). Voces Híbridas. La Literatura de Chicanas y Latinas en Estados Unidos. Santiago: RIL Editores.

Tabet, P. (3 de mayo 2009). La sexualidad que no existe. En M-E. Handman ¿La prostitución es siempre sometimiento? La Jornada (152). Recuperado de: http:// www.jornada.unam.mx/2009/03/05/ls-portada.htm

Vitiello, V. (1998). Genealogía de la modernidad. Argentina: Losada. 